\title{
Pentingnya Edukasi Ruang Lingkup K3 dalam Keperawatan di Rumah Sakit
}

\author{
Queen Agave (queenasiregar@gmail.com)
}

\section{Latar Belakang}

Pelaksanaan Kesehatan dan Keselamatan Kerja (K3) yaitu salah satu bentuk usaha untuk membuat tempat kerja yang aman, sehat, bebas dari pencemaran lingkungan, hingga dapat kurangi dan atau bebas dari kecelakaan kerja dan penyakit akibat kerja yang selanjutnya dapat tingkatkan efisiensi dan produktivitas kerja. Kecelakaan kerja tidak saja menyebabkan korban jiwa ataupun kerugian materi untuk pekerja dan entrepreneur, namun dapat juga mengganggu sistem produksi secara detail, mengakibatkan kerusakan lingkungan yang selanjutnya akan beresiko pada orang-orang luas.

Penyakit Akibat Kerja (PAK) dan Kecelakaan Kerja (KK) di kelompok petugas kesehatan dan non kesehatan kesehatan di Indonesia belum terekam dengan baik. Bila kita tekuni angka kecelakaan dan penyakit akibat kerja di beberapa negara maju (dari beberapa penilaian) memberikan kecenderungan penambahan prevalensi. Sebagai aspek penyebabnya, sering terjadi karena kurangnya kesadaran pekerja dan kwalitas dan ketrampilan pekerja yang kurang mencukupi. Banyak pekerja yang menyepelekan resiko kerja, hingga tidak memakai alatalat pengaman meskipun telah ada.

Dalam Undang-Undang Nomor 23 Th. 2003 mengenai Kesehatan, Pasal 23 dinyatakan kalau usaha Kesehatan dan Keselamatan Kerja (K3) harus diadakan di semua tempat kerja, terutama tempat kerja yang memiliki resiko bahaya kesehatan, mudah terjangkit penyakit atau memiliki karyawan paling sedikit 10 orang. Bila memerhatikan isi dari pasal diatas maka jelaslah kalau Tempat tinggal Sakit (RS) termasuk kedalam persyaratan tempat kerja dengan beragam ancaman bahaya yang bisa menyebabkan efek kesehatan, bukan sekedar pada beberapa pelaku segera yang bekerja di RS, namun juga pada pasien ataupun pengunjung RS.

Potensi bahaya di RS, selain penyakit-penyakit infeksi ada juga potensi bahaya-bahaya lain yang memengaruhi kondisi dan keadaan di RS, yakni kecelakaan (peledakan, kebakaran, kecelakaan yang berhubungan dengan instalasi listrik, dan sumber-sumber cidera yang lain. 


\section{Metode}

Metode ini menggunakan metode kualitatif analisis berlandaskan teori dari buku, jurnal, e-book ataupun sumber informasi lainnya yang memuat informasi dengan Ruang Lingkup K3 dalam Keperawatan. Dengan metode ini informasi pembahasan mengenai ruang lingkup K3 dalam keperawatan bagi seorang perawat dapat memahami dan mempelajari tentang system manajemen K3 RS, tujuan SM K3 RS, dan ruang lingkup K3 di rumah sakit. 


\section{Hasil}

Kesehatan, Keselamatan, dan Keamanan Kerja, biasa disingkat K3 adalah suatu upaya guna memperkembangkan kerja sama, saling pengertian dan partisipasi efektif dari pengusaha atau pengurus dan tenaga kerja dalam tempat - tempat kerja untuk melaksanakan tugas dan kewajiban bersama dibidang keselamatan, kesehatan, dan keamanan kerja dalam rangka melancarkan usaha berproduksi.

Melalui Pelaksanaan K3LH ini diharapkan tercipta tempat kerja yang aman, sehat, bebas dari pencemaran lingkungan, sehingga dapat mengurangi atau terbebas dari kecelakaan kerja dan penyakit akibat kerja. Jadi, pelaksanaan K3 dapat meningkatkan Efisiensi dan Produktivitas Kerja.

Adapun pengertiannya dibagi menjadi 2 pengertian, yaitu

\section{Secara Filosofis}

Suatu pemikiran atau upaya untuk menjamin keutuhan dan kesempurnaan baik jasmani maupun rohani, tenaga kerja pada khususnya dan masyarakat pada umumnya terhadap hasil karya dan budayanya menuju masyarakat adl dan makmur.

\section{Secara Keilmuan}

Ilmu pengetahuan dan penerapannya dalam usaha mencegah kemungkinan terjadinya kecelakaan dan penyakit akibat kerja.

Tujuan dari K3 sendiri adalah untuk :

1.Untuk memelihara kesehatan dan keselamatan lingkungan kerja.

2.Untuk menciptakan tempat kerja yang aman, sehat dan bebas dari pencemaran lingkungan, sehingga dapat mengurangi dan atau bebas dari kecelakaan dan PAK yang pada akhirnya dapat meningkatkan sistem dan produktifitas kerja. 


\section{Pembahasan}

\section{RUANG LINGKUP K3}

Ruang lingkup tindakan K3 dilakukan di setiap pekerjaan, kapanpun dan di manapun. Tindakan keselamata kerja dilakukan di tempat kerja, di lingkungan keluarga /rumah tangga, lingkungan masyarakat. Adapun syarat-syarat pelaksanaan K3 diperuntukan untuk:

1) Mencegah dan mengurangi kecelakaan

2) Membuat jalan penyelamatan (emergency exit)

3) Memberi pertolongan pertama (first aids/PPPK)

4) Memberi peralatan pelindung pada pekerja dan alat kerja

5) mempertimbangkan faktor-faktor kenyamanan kerja

6) Mencegah dan mengendalikan timbulnya penyakit fisik

7) Memelihara ketertiban dan kebersihan kerja

8) Mengusahakan keserasian antar pekerja, perkakas, lingkungan dan proses kerja.

Adapun aspek keselamatan kerja jika dilakukan di bengkel perlu ada tanggung jawab moral dan komitmen, adanya kemampuan sumber daya manusia, dan tindakan pencegahan. Tujuan utama kesehatan kerja antara lain meliputi : Pencegahan dan pemberantasan penyakit-penyakit dan kecelakaan akibat kerja; Pemeliharaan dan peningkatan kesehatan dan gizi tenaga kerja; Perawatan, efisiensi dan produktifitas tenaga kerja; Pemberantasan kelelahan tenaga kerja dan meningkatkan kegairahan serta kenikmatan kerja; Perlindungan masyarakat luas dari bahaya-bahaya yang mungkin ditimbulkan oleh produk-produk kesehatan.

Ada dua hal dalam penanganan resiko keselamatan kerja, yaitu resiko fisik tempat kerja, dan resiko kesehatan kerja. Resiko keselamatan kerja meliputi aspek-aspek dari lingkungan kerja yang dapat menyebabkan kerusakan fisik tempat kerja, alat dan manusia. Resiko kesehatan kerja meliputi aspek-aspek lingkungan kerja yang dapat menyebabkan kondisi tidak sehat pada pekerja yang dapat menimbulkan kerusakan atau kerugian baik fisik maupun psikis dalam jangka waktu tertentu.

Syarat Keselamatan Kerja harus mengarah pada mencegah dan mengurangi terjadinya kecelakaan; mencegah, mengurangi, dan memadamkan kebakaran; mencegah dan mengurangi bahaya peledakan; memberi kesempatan atau jalan menyelamatkan diri 
pada waktu kebakaran; memberi pertolongan pada kecelakaan; membeli alat-alat pelindung diri pada para pekerja. Untuk itu, perlu dilakukan tindakan preventif, dengan cara setiap pekerjaan harus dilakukan secara benar sesuai dengan SOP, ada alur kerja yang jelas; menyiapkan dokter kesehatan; dilakukaknya pelatihan PPPK bagi semua SDM yang terlibat dalam pekerjaan, pembentukan seksi dan pasukan khusus, perencanaan gedung, ruang, bengkel tempat kerja sesuai standar, pemahaman terhadap UU K3; kedisiplinan, ketaatan dan kepatuhan; kontrol, evaluasi dan pengembangan preplacement; pemeriksaan priodic; perencanan jangka pendek dan panjang.

\section{RUANG LINGKUP K3 DALAM KEPERAWATAN}

Keselamatan dan Kesehatan Kerja Untuk Perawat di Rumah Sakit; Dalam dunia kesehatan, tentunya petugas kesehatan menjaga dan meningkatkan kesehatan klien namun juga menjaga dan meningkatkan kesehatan dan terlebih keselamatan kerja dari petugas kesehatan tersebut (dalam hal ini perawat). Menurut Occupational Safety and Health Administration (OSHA, 2004) yang merupakan agen federal dalam bidang kesehatan mengatakan misinya untuk merancang dan menjamin keselamatan dan kesehatan kerja dari pekerja dengan menegakan sesuai standard, memberi pelatihan, penyuluhan, dan pendidikan ; dan mendirikan kemitraan dan mendorong terus menerus peningkatan keselamatan dan kesehatan kerja.

Ada beberapa hal tentang keselamatan kerja perawat di rumah sakit :

A. Nurse Staffing Levels

Penyetaraan kerja dalam bagian kesehatan, khususnya ruang lingkup k3 dalam keperawatan di rumah sakit telah menjadi perhatian yang menonjol. Pembagian tenaga kerja atau staff yg tidak memadai menyebabkan terjadinya kelelahan pada perawat yang menyebabkan cenderung terjadi keselaahan yang dapat membahayakan pasien ataupun perawat tersebut. American Nurse Association (ANA) telah melakukan kampanye besar-besaran bertema "Staffing Saves Lives" hal tersebut memberi gambaran kalau penyetaraan tenaga kerja sangat besar hubungannya dengan Kesehatan dan Keselamatan kerja untuk perawat.

B. Infection as an Occupational Hazard 
Penularan infeksi yaitu perhatian utama ketika perawat merawat pasien infeksi. Dengan adanya infeksi maka penaganan dan perlu perahtian ekstra dari petugas kesehatan untuk menangani pasien ini. Biasanya, disetiap rumah sakit memiliki petugas kesehatan khusus yang menangani permasalahan infeksi ini. Kewaspadaan universal telah diamanatkan oleh Keselamatan dan Kesehatan Kerja Administration (OSHA) kalau harus melindungi perawat dari pathogen darah. Karena darah dapat menularkan penyakit HIV, Hepatitis B dan lainnya yang dapat menyebar melalui darah. Salah satu tindakan utama dalam menjaga agar tidak tejadi infeksi maka harus ada pengaturan khusus tentang limbah jarum bekas, selain itu RS harus menyediakan sarung tangan (glove) atau kaca mata pelindung dalam melakukan kontak denganpasien infeksi. American Nurse Association (ANA) telah aktif dalam advokasi tempat kerja berkaitan dengan luka jarum suntik dan mensupport melaui situs website ditujukan untuk tema ini.

\section{Hazardous Chemical Agents}

Bicara tentang zat kimia beresiko yang ada di rumah sakit maka perlu juga perhatian khusunya untuk perawat anastesi atau para perawat fisiotherapy. Contohnya gas anastesi bisa membuat malformasi janin yang membuat bisa keguguran spontan pada wanita hamil yang terpapar secara terus menerus. Diperlukan protocol khusus dalam pengolahan penggunaan ataupun pemrosesan limbah zat beracun ini. RS bertanggungjawab dalam menyediakan perlengkapan yang di butuhkan untuk menjaga keselamatan perawat dalam memakai beberapa zat ini.

\section{Sistem Manajemen K3-RS}

Sistem manajemen K3-RS adalah bagian dari sistem manajemen RS keseluruhannya yang mencakup susunan organisasi, rencana, tanggung jawab, proses, prosedur, sistem, dan sumber daya yang diperlukan untuk pengembangan, aplikasi, pencapaian, dan pemeliharaan kebijakan kesehatan dan keselamatan kerja dalam rencana ingindalian kemungkinan yang terkait dengan aktivitas kerja manfaat terwujudnya tempat kerja yang sehat, aman, efektif, dan produktif. Adapun Step mengaplikasi K3-RS adalah :

- Step persiapan 
Prinsip manajemen : kebijakan, penyediaan dana, fasilitas dan prasarana untuk mensupport aktivitas K3 RS, membuat Unit Organisasi K3 di RS yang terlihat dalam susunan organisasi RS

Susunan Unit K3-RS terbagi dalam :

Bagian I : Bagian pengamanan perlengkapan medik, pengamanan radiasi dan limbah radioaktif

Bagian II : Bagian pengamanan perlengkapan nonmedik, pengamanan dan keselamatan bangunan

Bagian III : Bagian pengembangan sanitasi fasilitas kesehatan

Bagian IV : Bagian service kesehatan kerja dan mencegah penyakit akibat kerja

Bagian V : Bagian mencegah dan penanggulangan bencana

- Step Pemantauan dan evluasi

1. Inspeksi dan audit program $\mathrm{K} 3$

2. Perbaikan dan pengendalian K3 yang didasarkan berdasar hasil temuan dari audit dan inspeksi

3. Referensi dan tindak lanjut hasil pelajari program K3

4. Tujuan SM-K3RS

Membuat suatu system kesehatan dan keselamatan kerja dirumah sakit dengan melibatkan unsur manajemen, karyawan, keadaan dan lingkungan kerja yang terintegrasi dalam rencana menghindar dan kurangi kecelakaan dan penyakit akibat kerja.

5. Ruang lingkup K3 di Rumah Sakit

1. Fasilitas higene yang memonitor dampak lingkungan kerja pada tenaga kerja diantaranya pencahayaan, bising, suhu/iklim kerja.

2. Fasilitas Keselamatan kerja yang mencakup pengamanan pada perlengkapan kerja, penggunaan alat pelindung diri dan sinyal/rambu-rambu peringatan dan alat pemadam kebakaran.

3. Fasilitas Kesehatan Kerja yang mencakup kontrol awal, berkala dan khusus, gizi kerja, kebersihan diri dan lingkungan.

4. Ergonomi yakni kesehatan pada alat kerja dengan tenaga kerja 


\section{Penutup}

Keselamatan dan Kesehatan Kerja Untuk Perawat di Rumah Sakit; Dalam dunia kesehatan, tentunya petugas kesehatan menjaga dan meningkatkan kesehatan klien namun juga menjaga dan meningkatkan kesehatan dan terlebih keselamatan kerja dari petugas kesehatan tersebut (dalam hal ini perawat). Keselamatan pasien merupakan pencegahan cidera terhadap pasien. Pencegahan cidera didefinisikan sebagai bebas dari bahaya yang terjadi dengan tidak sengaja atau dapat dicegah sebagai hasil perawatan medis. Sedangkan praktek keselamatan pasien diartikan sebagai menurunkan risiko kejadian yang tidak diinginkan yang berhubungan dengan paparan terhadap lingkup diagnosis atau kondisi perawatan medis. Ada beberapa hal tentang keselamatan kerja perawat di rumah sakit yaitu Nurse Staffing Levels, Infection as an Occupational Hazard, Hazardous Chemical Agents, Ergonomic Hazards in the Workplace, Violence in the Workplace. 


\section{Daftar Pustaka}

1. Berliana, R. (2019). TINJAUAN SISTEM MANAJEMEN K3 DALAM MENDUKUNG PENCAPAIAN AKREDITASI RUMAH SAKIT (Studi Kasus di RSIA X Kota Semarang) (Doctoral dissertation, UNNES).

2. Ernawati, N., \& Nurlelawati, E. (2017). Faktor-Faktor Yang Berhubungan Dengan Pelaksanaan Penerapan K3 Pada Tenaga Kesehatan di RSIA Permata Sarana Husada Periode Februari 2015. Jurnal Akademi Keperawatan Husada Karya Jaya, 3(1).

3. Handayani, L. T. (Peer review+ Similarity) Analisis jalur keselamatan dan kesehatan kerja dengan kepuasan terhadap kinerja perawat dalam memberikan asuhan keperawatan di RS di Jember.

4. Ivana, A., Widjasena, B., \& Jayanti, S. (2014). Analisa Komitmen Manajemen Rumah Sakit (RS) terhadap Keselamatan dan Kesehatan Kerja (K3) pada RS Prima Medika Pemalang. Jurnal Kesehatan Masyarakat (e-Journal), 2(1), 35-41.

5. KURNIAWAN, Y. (2017). HUBUNGAN SELF REGULATION DENGAN PEMAKAIAN ALAT PELINDUNG DIRI (APD) SEBAGAI UPAYA KESELAMATAN KESEHATAN KERJA (K3) PADA PEKERJA PT. SUMBER GAS INTI UTAMA KOTA PROBOLINGGO (Doctoral dissertation, University of Muhammadiyah Malang).

6. MASKUR, A. (2015). Analisis Persepsi Pekerja Terhadap Faktor Eksternal yang Mempengaruhi Perilaku Penggunaan Alat Pelindung Diri (APD) Sebagai Upaya Keselamatan dan Kesehatan Kerja (K3) Studi Pada Pekerja Bagian Teknik dan Permainan, Kolam dan Pangan, dan Service Center di Taman Rekreasi Sengkaling Kota Malang (Doctoral dissertation, University of Muhammadiyah Malang).

7. Nazirah, R., \& Yuswardi, Y. (2017). PERILAKU PERAWAT DALAM PENERAPAN MANAJEMEN KESEHATAN DAN KESELAMATAN KERJA (K3) DI ACEH. Idea nursing journal, 8(3).

8. Simamora, R. H. (2018). Buku ajar keselamatan pasien melalui timbang terima pasien berbasis komunikasi efektif: SBAR. Medan: USUpress.

9. Simamora, R. H. (2019). Buku ajar pelaksanaan identifikasi pasien. Uwais Inspirasi Indonesia.

10. Simanullang, E., Putri, N. M., Sembiring, M., \& Sinuhaji, L. (2019). Analisis Manfaat Teh Kurkumin Kunyit Dan Pemakaian K3 Pada Petani Wanita Untuk Pencegahan Kanker Multiple Myeloma Di Berastagi Kab. Karo Tahun 2019. DINAMIKA KESEHATAN: JURNAL KEBIDANAN DAN KEPERAWATAN, 10(2), 609-621.

11. SITOHANG, R. B. (2019). HUBUNGAN PERILAKU PERAWAT DENGAN PENERAPAN KESELAMATAN DAN KESEHATAN KERJA (K3) DI INSTALASI GAWAT DARURAT (IGD) RSU BUNDA THAMRIN TAHUN 2019 (Doctoral dissertation, Institut Kesehatan Helvetia).

12. Suryati Ismail, S. I., A'yun, Q., A'yun, Q., \& Siti Hidayati, S. H. (2019). HUBUNGAN PENERAPAN KESEHATAN DAN KESELAMATAN KERJA DENGAN KEPUASAN KERJA MAHASISWA DI LABORATORIUM PELAYANAN ASUHAN JURUSAN KEPERAWATAN GIGI MANADO (Doctoral dissertation, Poltekkes Kemenkes Yogyakarta). 